\title{
Antibiotic resistance profiles of Pseudomonas aeruginosa strains isolated from dogs with otitis externa
}

\author{
Tansu Bıçakcıoğlu1 (), Şimal Yörük ${ }^{2}$ (), Hamit Kaan Müştak ${ }^{3}$ () \\ 1,2,3 Ankara University Faculty of Veterinary Medicine, Department of Microbiology, Ankara, Turkey.
}

Geliş Tarihi / Received: 28.08.2021, Kabul Tarihi / Accepted: 14.12.2021

\begin{abstract}
Pseudomonas aeruginosa is an important pathogen that is frequently isolated from otitis cases in dogs, known to have high intrinsic and acquired resistance mechanisms to resist most antibiotics, and the ability to develop multiple antibiotic resistance. The aim of this study was to determine the antibiotic resistance profile of $P$. aeruginosa strains isolated from dogs with otitis externa symptoms. Totally $43(26.70 \%) P$. aeruginosa strains were isolated from 170 ear swab samples and all these strains were subjected to disk diffusion susceptibility testing and the resistance profiles of the strains were found to be as follows; $100 \%$ to trimethoprim sulfamethoxazole, $93.02 \%$ to doxycycline, $79.06 \%$ to neomycin, $58.13 \%$ to oxytetracycline, $34.88 \%$ to enrofloxacin, $25.58 \%$ to tobramycin, $20.93 \%$ to gentamicin, $13.95 \%$ to ciprofloxacin, $9.30 \%$ to amikacin, $4.65 \%$ to polymyxin B. Furthermore, multiple antibiotic resistance was detected in a total of $17(39.53 \%) P$. aeruginosa strains. As a result, it was understood that the most common Gram-negative bacteria isolated from otitis externa cases of dogs was $P$. aeruginosa and these isolates have shown high resistance to antibiotics from many antibiotic groups.
\end{abstract}

Keywords: Antibiotic resistance, Dog, Otitis externa, Pseudomonas aeruginosa.

\section{Otitis eksternalı köpeklerden izole edilen Pseudomonas aeruginosa suşlarının antibiyotik direnç profilleri}

\begin{abstract}
Özet: Pseudomonas aeruginosa, köpeklerin otitis vakalarından sıklıkla izole edilen bir patojendir ve çoğu antibiyotiğe karşı birçok içsel ve edinilmiş direnç mekanizmasına sahip, çoklu antibiyotik direnci geliştirme kabiliyeti olduğu bilinen bir bakteridir. Bu çalışmanın amacı, otitis eksterna semptomları gösteren köpeklerden izole edilen $P$. aeruginosa suşlarının antibiyotik direnç profillerinin belirlenmesidir. 170 kulak sürüntüsü örneğinden toplam 43 $(\% 26,70)$ P. aeruginosa suşu izole edildi ve bu suşların tümü disk difüzyon duyarlılık testine tabi tutuldu. İzole edilen P. aeruginosa suşlarının direnç profilleri trimetoprim sülfametoksazole $\% 100$, doksisikline $\% 93,02$, neomisine $\% 79,06$, oksitetrasikline $\% 58,13$, enrofloksasine $\% 34,88$, tobramisine $\% 25,58$, gentamisine $\% 20,93$, siprofloksasine $\% 13,95$, amikasine \%4,30, polimiksin B'ye \%4,65 şeklinde bulundu. Ayrıca toplam $17(\% 39,53)$ P. aeruginosa suşunda çoklu antibiyotik direnci saptandı. Sonuç olarak köpeklerin otitis eksterna vakalarından en sık izole edilen Gram-negatif bakterinin P. aeruginosa olduğu ve bu izolatların farklı gruplardan antibiyotiklere yüksek direnç gösterdiği anlaşıldı.
\end{abstract}

Anahtar kelimeler: Antibiyotik direnci, Köpek, Otitis eksterna, Pseudomonas aeruginosa.

\section{Introduction}

Otitis externa is an acute or chronic inflammation of the external ear canal. The incidence of otitis externa in small animal medicine is around $20 \%$ (Cole 2004). Infectious otitis externa which is a multifactorial disease; arise as secondary complications of primary or predisposing causes such as atopic dermatitis, chronic irritation, conformational disorders, excessive moisture, obstructive causes, foreign bodies, metabolic diseases, ectoparasites, keratinization disorders (Graham-Mize and Rosser 2004).

The infectious agents that cause otitis externa are mostly bacteria, yeast and fungi (Shaw 2016). Staphylococcus spp, Pseudomonas aeruginosa,
Streptococcus spp., Proteus spp., Escherichia coli, Enterococcus spp. are the most common bacterial agents that are frequently isolated from canine bacterial otitis externa cases (Petrov et al. 2013; Lee et al. 2019). Among yeasts such as Malassezia pachydermatis and Candida spp. are also frequently isolated from canine otitis externa cases with or without bacterial agents (Blanco et al. 2000; Yapicier et al. 2018).

$P$. aeruginosa is the most frequently isolated Gram-negative bacteria in canine otitis externa cases. P. aeruginosa is a rod shaped, aerobic, opportunistic bacteria which is frequently found in many environments such as soil, water, organic material and 
is not found in the normal ear flora of dogs (Morris et al. 2017; Pye 2018).

$P$. aeruginosa is intrinsically resistant to many antibiotic groups. This intrinsic resistance can be associated with different mechanisms such as low outer membrane permeability, chromosomal AmpC $\beta$-lactamase production, and the presence of a large number of genes encoding efflux pumps that cause multiple antibiotic resistance (Hancock 1998). P. aeruginosa may have resistance to most of penicillin, $\beta$-lactam group antibiotics, often aminoglycoside antibiotics, chloramphenicol and tetracyclines (Mekić et al. 2011; Penna et al. 2011).

Antibiotic resistance is a remarkable problem in both public and animal health. Increasing incidence of $P$. aeruginosa with increased intrinsic resistant strains and multiple antibiotic resistance makes it difficult to select antibiotics for treatment (Rubin et al. 2008; Pye 2018). Groups of antibiotics routinely used against $P$. aeruginosa infections in small animal medicine include aminoglycosides, fluoroquinolones, polymyxins, tetracyclines and potentiated sulfonamides (Martino De et al. 2016; Pye 2018). Making the selection of antibiotics used in the treatment according to the results of antibiotic susceptibility testing provides the increasing success of treatment regimes.

In this study, it was aimed to determine the prevalence of $P$. aeruginosa in otitis externa cases and the resistance of the strains against routinely used antibiotics.

\section{Material and Method}

\section{Sample Collection}

In this study, swab samples taken from the outer ear canal of 170 dogs with a clinical diagnosis of otitis externa sent from 13 veterinary clinics in the Ankara region between September 2019 and December 2020 were used. The selection of the dogs participating in the study was made by physical aurial examination (head shaking, aurial hyperemia and pruritus, discharge from the ear canal, unpleased odor, erythema, trauma due to scratching itself, pain on palpation, alopecia, ulceration, etc.) and otoscopic examination findings. Specimens were collected from the external ear canal of dogs using Amies Agar Gel Swabs (Oxoid, Hampshire, UK). The samples taken into the transport medium were kept at $4^{\circ} \mathrm{C}$ until meintened and processed within 24 hours. The swab samples have been examined in terms of both bacteriological and mycological aspects. P. ae- ruginosa AUVFM-07/01 strain obtained from Ankara University Faculty of Veterinary Medicine Department of Microbiology Culture Collection was used as positive control in all tests.

\section{Bacteriological and Mycological Examination}

In bacteriological examination, specimens which obtained using sterile swabs were inoculated on blood agar containing 5\% sheep blood, MacConkey (MC) Agar (Oxoid CM0115) and Eosin Methylene Blue (EMB) agar (Oxoid CM0069B) and incubated at $37^{\circ} \mathrm{C}$ for $24-48$ hours under aerobic conditions. Colonies were Gram stained and inspected according to their macroscopic and microscopic morphology. Alongside, biochemical tests such as catalase, oxidase, lactose fermentation, coagulase, indole, methyl red, Voges-Proskauer, citrate, urease, oxidation/ fermentation tests were performed to identify genus and species. Cystine-Lactose-Electrolyte Deficient (CLED) Agar (Oxoid CM0301) was also used as a differential agar for the identification of pyocyanin formation of $P$. aeruginosa. Isolates were identified at the genus and species level using staining, biochemical tests and differential mediums (Holt et al. 1994; Quinn et al. 1994).

For mycological examination, collected swabs were inoculated on Sabouraud Dextrose Agar (SDA) (Oxoid CM0041) and incubated at $25^{\circ} \mathrm{C}$ for $2-4$ weeks in an aerobic environment and colonies were controlled daily. Inoculations were also made on Chromogenic Candida agar (Oxoid CM1002) to differentiate Candida species in yeast isolations and incubated at $37-42^{\circ} \mathrm{C}$ for 48 hours. Mycological diagnosis was made by examining the incubation time and macroscopic/microscopic morphology of the colonies. In macroscopic examination, colonies were examined by considering their pigmentation and structure. In microscopic examination, colonies were stained with lactophenol cotton blue solution using cellophane tape method (Ghannoum and Isham 2009). Microscopically, hypha, septum, macroconidium, microconidium and spore structures belonging to fungal colonies were examined and diagnosed by classical mycological culture methods (Holt et al. 1994; Quinn et al. 1994).

\section{Antibiotic Susceptibility Testing}

Antibiotic susceptibility test was performed by the disk diffusion method recommended by Clinical \& Laboratory Standards Institute (CLSI 2019). P. aeruginosa strains identified by conventional methods were inoculated on Mueller-Hinton (MH) agar (Oxo- 
id CM0337). Antimicrobial susceptibility test disks (Oxoid, Hampshire, UK); gentamicin (CN10 $\mu \mathrm{g}$ ), oxytetracycline (OT $30 \mu \mathrm{g})$, tobramycin (TOB $10 \mu \mathrm{g}$ ), polymyxin B (PB $300 \mathrm{U}$ ), enrofloxacin (ENR $5 \mu \mathrm{g}$ ), neomycin (N $30 \mu \mathrm{g})$, trimethoprim sulfamethoxazole (SXT $25 \mu \mathrm{g}, 1.25 \mu \mathrm{g}-23.75 \mu \mathrm{g}$ ), doxycycline (DO 5 $\mu \mathrm{g})$, ciprofloxacin (CIP $5 \mu \mathrm{g}$ ), amikacin (AK $30 \mu \mathrm{g}$ ) were used. Agar plates were incubated at $37^{\circ} \mathrm{C}$ for 18-24 hours and inhibition zone diameters were measured for each disk according to CLSI standards (CLSI 2019; CLSI 2020). Escherichia coli ATCC 25922 strain was used as positive control in all tests. P. aeruginosa strains were defined as multi-drug resistant (MDR) in the case of resistance to one or more antibiotics from at least three different antibiotic groups (Magiorakos et al. 2012).

\section{Results}

\section{Bacterial and Mycological Examination Results}

No growth was observed in 9 (5.2\%) of the 170 swab samples. Staphylococcus spp. (40.37\%), P. aeruginosa
(26.70\%), Streptococcus spp. (18.01\%), E. coli (4.96\%), Proteus spp. (4.34\%), Corynebacterium spp. (3.10\%) and Enterococcus spp. (1.86\%) were isolated among 161 samples.

Fungi and yeast growth were observed in 58 (34.11\%) of 170 ear swab samples. According to the results 38 (65.51\%) Malassezia spp., 11 (18.96\%) Candida albicans, 5 (8.62\%) Aspergillus spp. and 4 (6.89\%) Penicillium spp. were isolated.

\section{Antimicrobial Susceptibility Test Results}

Among 43 P. aeruginosa strains; 43 (100\%) of them were found resistant to trimethoprim sulfamethoxazole, 40 (93.02\%) to doxycycline, 34 (79.06\%) to neomycin, $25(58.13 \%)$ to oxytetracycline, 15 (34.88\%) to enrofloxacin, 11 (25.58\%) to tobramycin, 9 (20.93\%) to gentamicin, $6(13.95 \%)$ to ciprofloxacin, $4(9.3 \%)$ to amikacin and $2(4.65 \%)$ to polymyxin B (Table 1$)$. Some of these resistant strains of $P$. aeruginosa were found resistant to antibiotics from two or more antibiotic groups. Multiple antibiotic resistance profiles have been shown in Table 2.

Table 1. Antimicrobial resistance profiles of $P$. aeruginosa strains.

\begin{tabular}{|c|c|c|c|c|}
\hline Antimicrobial Classes & $\begin{array}{l}\text { Antimicrobial } \\
\text { Agents }\end{array}$ & $\begin{array}{c}\text { Number of Isolates } \\
(n=43)\end{array}$ & $\begin{array}{l}\text { Zone diameter breakpoint } \\
\text { for resistant strains ( } \mathrm{mm})\end{array}$ & Resistance (\%) \\
\hline \multirow{2}{*}{ Fluoroquinolones } & $\mathrm{CIPb}$ & 6 & $\leq 15$ & 13.95 \\
\hline & ENR $^{a}$ & 15 & $\leq 16$ & 34.88 \\
\hline \multirow{4}{*}{ Aminoglycosides } & $\mathrm{AK}^{\mathrm{a}}$ & 4 & $\leq 14$ & 9.3 \\
\hline & $\mathrm{CN}^{\mathrm{a}}$ & 9 & $\leq 12$ & 20.93 \\
\hline & $\mathrm{TOB}^{\mathrm{b}}$ & 11 & $\leq 12$ & 25.58 \\
\hline & $\mathrm{N}^{\mathrm{a}}$ & 34 & $\leq 17$ & 79.06 \\
\hline Polymyxins & $\mathrm{PB}^{\mathrm{b}}$ & 2 & $\leq 11$ & 4.65 \\
\hline \multirow{2}{*}{ Tetracyclines } & $\mathrm{DO}^{\mathrm{b}}$ & 40 & $\leq 18$ & 93.02 \\
\hline & $\mathrm{OT}^{\mathrm{b}}$ & 25 & $\leq 18$ & 58.13 \\
\hline Sulfonamides & SXTb & 43 & $\leq 23$ & 100 \\
\hline
\end{tabular}

n: Total number of isolates tested. AK: Amikacin, ENR: Enrofloxacin, N: Neomycin, OT: Oxytetracycline, TOB: Tobramycin, CN: Gentamicin, DO: Doxycycline, SXT: Trimethoprim-sulfamethoxazole, CIP: Ciprofloxacin, PB: Polymyxin B.

a Zone diameter breakpoints according to Performance Standards for Antimicrobial Disk and Dilution Susceptibility Test for Bacteria Isolated from Animals; Approved Standard Document 5th ed. CLSI supplement VET01S (CLSI, 2020).

${ }^{\mathrm{b}}$ Zone diameter breakpoints according to Performance Standards for Antimicrobial Susceptibility Testing. 29th ed. CLSI supplement M100. Wayne, PA ABD (CLSI, 2019). 
Table 2. Multiple antibiotic resistance profiles of $P$. aeruginosa strains.

\begin{tabular}{lcc}
\hline $\begin{array}{l}\text { Multidrug } \\
\text { Resistance Profiles }\end{array}$ & $\begin{array}{c}\text { No. of MDR } \\
\text { Isolates }\end{array}$ & $\begin{array}{c}\text { Prevalence of } \\
\text { MDR Isolates }\end{array}$ \\
\hline DO, SXT, N, ENR, OT & 2 & 4.6 \\
\hline DO, SXT, N, ENR, AK & 1 & 2.3 \\
\hline DO, SXT, N, PB, CN & 1 & 2.3 \\
\hline DO, SXT, N, ENR & 3 & 6.9 \\
\hline DO, SXT, N, OT & 5 & 11.6 \\
\hline DO, SXT, N, AK & 1 & 2.3 \\
\hline DO, SXT, OT, TOB & 2 & 4.6 \\
\hline SXT, TOB, CIP, CN & 2 & 4.6 \\
\hline Total: & $\mathbf{1 7}$ & $\mathbf{3 9 . 5}$ \\
\hline
\end{tabular}

Antimicrobial agent groups: Tetracyclines: DO, OT; Fluoroquinolones: ENR, CIP; Aminoglycosides: AK, CN, N, TOB; Sulfonamides: SXT; Polymyxins: PB.

\section{Discussion and Conclusion}

Otitis externa cases in dogs can occur due to primary and secondary causes (Shaw 2016; Pye 2018). It was thought that the 9 swab samples with no growth were considered to be according to primary non-infectious causes such as allergic conditions, autoimmune disorders, hormonal disorders, and obstructive causes. The most common bacterial agents isolated from otitis externa cases of dogs belong to Staphylococcus spp. (Blanco et al. 2000; Turkyilmaz 2008; Penna et al. 2011; Petrov et al. 2013; Bajwa 2019). In this study, the prevalence of Staphylococcus spp. from dogs with otitis externa was determined as $40.37 \%$. This result supports the idea that Staphylococcus spp. is the most common bacteria isolated from dogs with otitis externa, as reported in other studies (Petrov et al. 2013; Paterson 2016; Korbelik et al. 2019). P. aeruginosa is not found in the normal ear flora of dogs, but it is frequently isolated from canine otitis cases. In this study, prevalence of $P$. aeruginosa (26.7\%) was found to be high which is similar to Hariharan et al. (17.5\%) (2006), Turkyilmaz (17\%) (2008), Bugden (35.5\%) (2013), Petrov et al. (17\%) (2013), Bourély et al. (27.5\%) (2019) and Dos Santos et al. (27.6\%) (2019) findings.

$P$. aeruginosa is frequently isolated from otitis cases and treatment is often unsuccessful due to its high antimicrobial resistance (Ghannoum and Isham 2009; Mekić et al. 2011; Bourély et al. 2019; Chan et al. 2019). This is explained by the knowledge that $P$. aeruginosa is a bacterium that has an intrinsic antibiotic resistance mechanism and can exhibit MDR and can also easily develop resistance to new antibiotics (Hancock 1998). It is known that $P$. aeruginosa has high intrinsic resistance to tetracycline, sulphonamide and quinolone group antibiotics (Mekić et al. 2011; Penna et al. 2011; Arais et al. 2016). In this study, all $P$. aeruginosa strains were found to be resistant to trimethoprim-sulfamethoxazole from the sulfonamide group among the antibiotics tested from five different groups. In similar studies, Schick et al. (69\%) (2007), Rubin et al. (57\%) (2008), Ozturk et al. (100\%) (2016) and Turkyilmaz (100\%) (2008) reported that $P$. aeruginosa was highly resistant to trimethoprim-sulfamethoxazole.

In this study, $P$. aeruginosa strains resistant to oxytetracycline $(58.1 \%)$ from tetracycline group is very similar to the findings of Ozturk et al. (50\%) (2016) and the resistance to doxycycline (93\%) is very similar to the findings of Martino et al. (78.3\%) (2016) and Petrov et al. (78.3\%) (2013).

The resistance of $P$. aeruginosa to antibiotics from the aminoglycoside group is provided by the inactivation of the antimicrobial agents by bacterial modifying enzymes (34). In this study, 90.7\% P. aeruginosa strains were found to be susceptible to amikacin. Petrov et al. (100\%) (2013), Schick et al. (81\%) (2007) and Park et al. (97.8\%) (2020) also found high sensitivity to amikacin in their studies. In this study, $P$. aeruginosa exhibited the highest sensitivity to amikacin among the aminoglycoside antibiotics tested. This is attributed to the opinion that amikacin has a low sensitivity to modifying enzymes, which is also reported in the literature (Poole 2005; Ekincioglu and Percin 2013).

Enrofloxacin is more lipophilic than ciprofloxacin (Davis et al. 2007). Therefore, efflux pumps, which are important in the elimination of fluoroquinolones, are known to more easily eliminate enrofloxacin (Wildermuth et al. 2007). Rubin et al. (2008) reported that $P$. aeruginosa strains isolated from dogs with diseases such as otitis, pyoderma, and soft tissue infections had 31\% resistance to enrofloxacin and $16 \%$ resistance to ciprofloxacin. In this study, prevalence of resistance to enrofloxacin and ciprofloxacin was found to be $34.8 \%$ and $13 \%$, respectively. Similar to this study, Park et al. (2020) reported that $P$. aeruginosa was more resistant to enrofloxacin than ciprofloxacin, thus supporting the view that $P$. aeruginosa exhibited higher resistance to enrofloxacin than ciprofloxacin.

$P$. aeruginosa strains isolated in this study exhibited high sensitivity (95.4\%) to polymyxin B that has also been reported similarly in other studies (Tam et al. 2005; Bugden et al. 2013; Pye et al. 2013; Hyun et al. 2018). Polymyxin B is one of the limited 
antibiotic options that can be used in the treatment of infections caused by Gram negative bacteria and especially $P$. aeruginosa that exhibit MDR, and is often preferred against $P$. aeruginosa in cases of otitis externa (Tam et al. 2005; Petrov et al. 2013). P. aeruginosa exhibits a very low intrinsic resistance to polymyxin B compared to other antibiotics and it is known that its ability to develop mutational resistance is limited (Fernández et al. 2013).

In this study, MDR prevalence (39.53\%) of $P$. aeruginosa strains was found to be similar to the MDR prevalence of the studies reported by Dos Santos et al. (61.9\%) (2019) and Eliasi et al. (92\%) (2020). In these studies, sulphonamide, tetracycline, fluoroquinolone and aminoglycoside group antibiotics, which are known to exhibit intrinsic resistance in $P$. aeruginosa, were found at high levels in MDR profile combinations (Turkyilmaz 2008; Eliasi et al. 2020). In addition, the ability of $P$. aeruginosa to develop acquired resistance also contributes to the formation of MDR (Pang et al. 2019).

As a result, in this study which was conducted in the Ankara region, it was confirmed that the most common Gram-negative bacteria causing otitis externa in dogs was $P$. aeruginosa. In this study, it was observed that the resistance profile of $P$. aeruginosa strains isolated from otitis externa cases of dogs against antibiotics selected from antibiotic groups known to have resistance was consistent with similar studies. For a successful treatment of otitis externa in this region, it was thought that antibiotics such as amikacin and polymyxin $B$, which $P$. aeruginosa strains showed low resistance, could be preferred instead of trimethoprim-sulfamethoxazole, doxycycline and oxytetracycline, which $P$. aeruginosa strains show high resistance. The high prevalence of multiple antibiotic resistant strains emphasizes once again the importance of antibiotic susceptibility testing in the selection of antibiotics for treatment.

Conflict of Interest: The authors declare that they have no conflict of interest.

Ethical Statement: The materials used in this study are swab samples collected during clinical examination.

\section{References}

Arais LR, Barbosa AV, Carvalho CA, Cerqueira AM. (2016) Antimicrobial resistance, integron carriage, and gyrA and gyrB mutations in Pseudomonas aeruginosa isolated from dogs with otitis externa and pyoderma in Brazil. Vet Dermatol. 27(2), 113-7e31. DOI: 10.1111/vde.12290.
Bajwa J. (2019) Canine otitis externa - Treatment and complications. Can Vet J. 60(1), 97-99.

Blanco JL, Guedeja-Marron J, Blanco I, Garcia ME. (2000) Optimum incubation conditions for the isolation of yeasts from canine otitis externa. J Vet Med Ser B. 47(8), 599-605. DOI: 10.1046/ j.1439-0450.2000.00390.

Borum AE, Cecen G, Demir G, Cetin C, Senturk S. (2014) Determination and Antimicrobial Susceptibility of Microorganisms Isolated from Otitis Externa with Dogs. Kocatepe Vet J. 7(1), 27-31. DOI: 10.5578/kvj.7337

Bourély C, Cazeau G, Jarrige N et al. (2019) Antimicrobial resistance patterns of bacteria isolated from dogs with otitis. Epidemiol Infect. 147, e121, 1-10. DOI: https://doi. org/10.1017/S0950268818003278

Bugden DL. (2013) Identification and antibiotic susceptibility of bacterial isolates from dogs with otitis externa in Australia. Aust Vet J. 91(1-2), 43-46. DOI: 10.1111/avj.1200

Chan WY, Khazandi M, Hickey EE, Page SW, Trott DJ, Hill PB. (2019) In vitro antimicrobial activity of seven adjuvants against common pathogens associated with canine otitis externa. Vet Dermatol. 30, 133-e38. DOI: https://doi. org/10.1111/vde. 12712

CLSI. (2020) Performance Standards for Antimicrobial Disk and Dilution Susceptibility Test for Bacteria Isolated from Animals; Approved Standard Document 5th ed. CLSI supplement VET01S.

CLSI. (2019) Performance Standards for Antimicrobial Susceptibility Testing. 29th ed. CLSI supplement M100. Wayne, PA ABD.

Cole LK. (2004) Otoscopic evaluation of the ear canal. Vet Clin North Am - Small Anim Pract. 34(2), 397-410. DOI: 10.1016/j. cvsm.2003.10.004.

Davis JL, Foster DM, Papich MG. (2007) Pharmacokinetics and tissue distribution of enrofloxacin and its active metabolite ciprofloxacin in calves. J Vet Pharmacol Ther. 30(6), 564-71. DOI: 10.1111/j.1365-2885.2007.00914.x.

Dos Santos JP, Júnior ÁF, Locce CC, Brasão SC, Bittar ER, Bittar JFF. (2019) Effectiveness of tobramycin and ciprofloxacin against bacterial isolates in canine otitis externa in Uberaba, Minas Gerais. Cienc Anim Bras. 20, 8-9. DOI: http://dx.doi. org/10.1590/1089-6891v20e-52164

Ekincioglu P, Percin D. (2013) Antibiotic Susceptibilities of Clinical Pseudomonas aeruginosa Isolates. Sağlık Bilimleri Dergisi (Journal of Health Sciences). 22(2), 141-149. DOI: https://doi. org/10.5505/abantmedj.2015.38981

Eliasi UL, Sebola D, Oguttu JW, Qekwana DN. (2020) Antimicrobial resistance patterns of Pseudomonas aeruginosa isolated from canine clinical cases at a veterinary academic hospital in South Africa. J S Afr Vet Assoc. 22; 91(0), e1-e6. DOI: 10.4102/ jsava.v91i0.2052.

Fernández L, Álvarez-ortega C, Wiegand I. et al. (2013) Characterization of the Polymyxin B Resistome of Pseudomonas aeruginosa. Antimicrob Agents Chemother. 57(1), 110-119. DOI: 10.1128/AAC.01583-12

Ghannoum MA, Isham NC. (2009) Clinical Mycology. 2nd ed., 375-384. Dermatophytes and dermatophytoses.

Graham-Mize CA, Rosser EJ. (2004) Comparison of microbial isolates and susceptibility patterns from the external ear canal of dogs with otitis externa. J Am Anim Hosp Assoc. 40(2), 102-108. DOI: 10.5326/0400102

Hancock REW. (1998) Resistance Mechanisms in Pseudomonas aeruginosa and Other Nonfermentative Gram-Negative Bacteria. Clin Infect Dis. 27(1), 93-S99. DOI: 10.1086/514909. 
Hariharan H, Coles M, Poole D, Lund L, Page R. (2006) Update on antimicrobial susceptibilities of bacterial isolates from canine and feline otitis externa. Can Vet J. 47(3), 253-255.

Holt JG, Krieg NR, Sneath PHA, Staley JT, Williams ST, (1994) Bergey's Manual of Determinative Bacteriology (Ninth Edition). Williams \& Wilkins. Baltimore.

Hyun JE, Chung TH, Hwang CY. (2018) Identification of VIM-2 metallo- $\beta$-lactamase-producing Pseudomonas aeruginosa isolated from dogs with pyoderma and otitis in Korea. Vet Dermatol. Jun;29(3):186-e68. doi: 10.1111/vde.12534.

Korbelik J, Singh A, Rousseau J, Weese JS. (2019) Characterization of the otic bacterial microbiota in dogs with otitis externa compared to healthy individuals. Veterinary Dermatology. 30(3), 228-e70. DOI: https://doi.org/10.1111/ vde. 12734

Lee GY, Lee HH, Hwang SY, Hong J, Lyoo KS, Yang SJ. (2019) Carriage of Staphylococcus schleiferi from canine otitis externa: antimicrobial resistance profiles and virulence factors associated with skin infection. J Vet Sci. 20(2): e6. DOI: 10.4142/jvs.2019.20.e6.

Magiorakos AP, Srinivasan A, Carey RB et al. (2012) Multidrugresistant, extensively drug-resistant and pandrug-resistant bacteria: an international expert proposal for interim standard definitions for acquired resistance. Clin Microbiol Infect. 18(3), 268-81. DOI: 10.1111/j.1469-0691.2011.03570.x.

Martino De L, Nocera FP, Mallardo K et al. (2016) An update on microbiological causes of canine otitis externa in Campania Region, Italy. Asian Pac J Trop Biomed. 6(5), 384-389. DOI: https://doi.org/10.1016/j.apjtb.2015.11.012

Mekić S, Matanović K, Šeol B. (2011) Antimicrobial susceptibility of Pseudomonas aeruginosa isolates from dogs with otitis externa. Vet Rec. 169(5), 125. DOI: 10.1136/vr.d2393

Morris DO, Davis MF, Palmeiro BS, O'Shea K, Rankin SC. (2017) Molecular and epidemiological characterization of canine Pseudomonas otitis using a prospective case-control study design. Vet Dermatol. 28(1), 118-e25. DOI: 10.1111/vde.12347

Ozturk D, Pehlivanoglu F, Turutoglu H, Sirin YS, Sababoglu E. (2016) Isolation and antibiotic susceptibility of microorganisms from dogs with otitis externa. Eurasian J Vet Sci. 32(2), 84-88. DOI: 10.1111/avj.12007

Pang Z, Raudonis R, Glick BR, Lin TJ, Cheng Z. (2019) Antibiotic resistance in Pseudomonas aeruginosa: Mechanisms and alternative therapeutic strategies. Biotechnology Advances. 37(1), 177-192. DOI: https://doi.org/10.1016/j. biotechadv.2018.11.013

Park Y, Oh J, Park S, Sum S, Song W, Chae J, Park H. (2020) Antimicrobial resistance and novel mutations detected in the gyrA and parC genes of Pseudomonas aeruginosa strains isolated from companion dogs. BMC Vet Res. Apr 15;16(1):111. doi: 10.1186/s12917-020-02328-0.
Paterson S. (2016) Discovering the causes of otitis externa. In Practice. 38, 7-11. DOI: 10.1136/inp.i470

Penna B, Thomé S, Martins R, Martins G, Lilenbaum W. (2011) In vitro Antimicrobial Resistance of Pseudomonas aeruginosa Isolated from Canine Otitis Externa in Rio De Janeiro, Brazil. Braz. J. Microbiol. 42, 1434-1436. DOI: 10.1590/S1517838220110004000027

Petrov V, Mihaylov G, Tsachev I, Zhelev G, Marutsov P, Koev K. (2013) Otitis externa in dogs: Microbiology and antimicrobial susceptibility. Rev Med Vet (Toulouse). 164(1), 18-22.

Poole K. (2005) Aminoglycoside resistance in Pseudomonas aeruginosa. Antimicrob Agents Chemother. 49(2), 479-87. DOI: 10.1128/AAC.49.2.479-487.2005.

Pye C. (2018) Pseudomonas otitis externa in dogs. Dermatologie Vétérinaire. 59, 1231-1234. PMID: 30410185. PMCID: PMC6190182.

Pye CC, Yu AA, Weese JS. (2013) Evaluation of biofilm production by Pseudomonas aeruginosa from canine ears and the impact of biofilm on antimicrobial susceptibility in vitro. Vet Dermatol. 24(4), 1-6. DOI: 10.1111/vde.12040

Quinn PJ, Carter ME, Markey B, Carter GR. (1994) Clinical Veterinary Microbiology. 237-242. London: Wolfe/Mosby.

Rubin J, Walker RD, Blickenstaff K, Bodeis-Jones S, Zhao S. (2008) Antimicrobial resistance and genetic characterization of fluoroquinolone resistance of Pseudomonas aeruginosa isolated from canine infections. Vet Microbiol. 131(1-2), 164172. DOI: 10.1016/j.vetmic.2008.02.018

Schick AE, Angus JC, Coyner KS. (2007) Variability of laboratory identification and antibiotic susceptibility reporting of Pseudomonas spp. isolates from dogs with chronic otitis externa. Vet Dermatol. 18(2), 120-126. DOI: 10.1111/j.13653164.2007.00581.x

Shaw S. (2016) Pathogens in otitis externa: Diagnostic techniques to identify secondary causes of ear disease. In Practice. 38, 12-16. DOI: https://doi.org/10.1136/inp.i461

Tam VH, Schilling AN, Vo G et al. (2005) Pharmacodynamics of Polymyxin B against Pseudomonas aeruginosa. Antimicrob Agents Chemother. 49(9), 3624-3630. DOI: 10.1128/ AAC.49.9.3624-3630.2005

Turkyilmaz S. (2008) Antibiotic susceptibility patterns of Pseudomonas aeruginosa strains isolated from dogs with otitis externa. Turkish J Vet Anim Sci. 32(1), 37-42

Wildermuth BE, Griffin CE, Rosenkrantz WS, Boord MJ. (2007) Susceptibility of Pseudomonas isolates from the ears and skin of dogs to enrofloxacin, marbofloxacin, and ciprofloxacin. J Am Anim Hosp Assoc. 43(6), 337-341. DOI: 10.5326/0430337

Yapicier OS, Sababoglu E, Kaya M, Ozturk D, Pehlivanoglu $F$ Turutoglu H. (2018) Fungal agents isolated from dogs with otitis externa. Mehmet Akif Ersoy Üniversitesi Vet Fakültesi Derg. 3(2), 121-124. DOI: 10.24880/maeuvfd.463762 